\title{
Viral Diversity in Autochthonous Croatian Grapevine Cultivars
}

Darko Vončina, Department of Plant Pathology, University of Zagreb Faculty of Agriculture, Zagreb, Croatia; Maher Al Rwahnih and Adib Rowhani, Department of Plant Pathology, University of California, Davis, USA; Mona Gouran, Foundation Plant Services, Davis, CA, USA; and Rodrigo P. P. Almeida, Department of Environmental Science, Policy, and Management, University of California, Berkeley, USA

\begin{abstract}
A survey was conducted on nine autochthonous grapevine cultivars grown along the Croatian coastal region. In total, 48 vines (44 from germplasm collection, 4 from vineyards) originating from 23 sites were tested for 26 viruses using molecular methods. Results revealed high infection rates with Grapevine leafroll-associated virus 3 (GLRaV-3); Grapevine virus A (GVA, both 91.7\%); Grapevine fleck virus (GFkV, 87.5\%); and Grapevine rupestris stem pitting-associated virus (GRSPaV, 83.3\%). Other detected viruses were: Grapevine fanleaf virus (GFLV); Grapevine leafroll-associated viruses 1, 2, and strains of 4 (GLRaV-1, GLRaV-2, GLRaV-4); Grapevine viruses B, D, F (GVB, GVD, GVF);

Grapevine red globe virus (GRGV); Grapevine vein feathering virus (GVFV); Grapevine Syrah virus 1 (GSyV-1); and Grapevine Pinot gris virus (GPGV). No virus-free vine was found. Mixed infections were determined in all vines, the number of viruses in a single vine ranged from three to nine. GLRaV-3 variant typing confirmed presence of group I, II, and III. Four vines with leaf deformation and mottling were positive for GPGV. Seven viruses (GLRaV-4-like group, GVD, GVE, GVF, GRGV, GSyV-1, and GVFV) were detected for the first time in Croatia. This survey confirmed the deteriorated sanitary status of autochthonous Croatian grapevine cultivars.
\end{abstract}

Plant pathogens have significant impacts on food production. In a time of intensive exchange of different planting material on national and international levels, data about distribution and economic importance of plant pathogens and plant diseases are crucial for their successful management. To decrease the negative impact that pathogens have, it is crucial to constantly work on their detection and geospatial distribution. Grapevine (Vitis vinifera L.) is an important plant crop with worldwide distribution. Throughout history, grapevines have been faced with challenges that changed European viticultural practice. Phylloxera (Viteus vitifoliae), a pest that was introduced in Europe from America in the 19th century, caused the "Great French Wine Blight" (Gale 2003). The use of American rootstocks solved the phylloxera problem, but resulted in the introduction of two fungal diseases: powdery (Erysiphe necator) and downy mildew (Plasmopara viticola) (Pearson and Goheen 1988). Demand for American rootstocks and priority given to grapevine varieties more resistant to fungal diseases resulted in dissemination of their planting material between continents and countries. Besides that, in many grape growing regions priority given to worldwide-grown cultivars (i.e., Chardonnay, Cabernet Sauvignon, etc.), promoted by wine companies and markets, caused irretrievable loss of autochthonous cultivars (Pouget 1988). Intensive exchange of planting material opened the space for dissemination of grapevine viruses, at the time a group of practically unknown pathogens (Hull 2002).

Grapevines have 65 reported viruses, the highest number known from a single crop (Martelli 2014a). However, only a fraction of these viral species is considered economically important. Because virus infection impacts crop quality and yield, data about virus distribution and frequency are important in the implementation of appropriate disease management practices. So far, measures for virus control in vineyards are mainly based on control of vectors (insects, mites, nematodes), use of virus-free planting material, and constant work on clonal and sanitary selection (Maliogka et al. 2015; Martelli and Boudon-Padieu 2006). For example, a California North Coast study on Grapevine leafroll-associated

Corresponding author: D. Vončina; E-mail: dvoncina@agr.hr

*The $\boldsymbol{e}$-Xtra logo stands for "electronic extra" and indicates that one supplementary figure and three supplementary tables are published online.

Accepted for publication 18 February 2017.

() 2017 The American Phytopathological Society virus 3 (GLRaV-3) showed benefits of using certified plant material of $\$ 0.40$ per vine, $\$ 533$ per acre, and $\$ 52.7$ million per year for the region (Fuller et al. 2015).

In Croatia viticulture has a long tradition dating back to the Bronze Age (Batović and Kukoč 1987). Today, approximately $15 \%$ of the Croatian population is associated with viticulture (Maletić et al. 2007). Croatia has two different viticultural regions: (i) continental, with continental temperate climate; and (ii) coastal, with influence of the Adriatic Sea and Mediterranean climate. In addition to popular cultivars (i.e., Chardonnay, Cabernet Sauvignon, Merlot, etc.), there are a significant number of autochthonous cultivars, primarily grown in coastal region. According to Maletić et al. (2015) there are at least 125 autochthonous grapevine genotypes that represent valuable national heritage.

The first report of grapevine viruses in Croatia included information on the spread and detrimental effect of viruses from infective degeneration complex (Šarić and Corte 1959). Viruses from the grapevine leafroll complex were reported three decades later (Topolovec-Pintarić 1990). Prevalence of GLRaV-3 in the coastal region has been documented (Karoglan Kontić et al. 2009b; Poljuha et al. 2010; Vončina et al. 2009, 2012), revealing infection of commercial vineyards and mixed infections with Grapevine virus A (GVA) and Grapevine fleck virus (GFkV). In the continental region, up to $52 \%$ vines surveyed were free of economically important viruses, with Grapevine leafroll-associated virus $1(\mathrm{GLRaV}-1)$ and GFkV as the most common viruses (Karoglan Kontić et al. 2009b; Vončina et al. 2012). To improve the quality of planting material and save endangered autochthonous cultivars from extinction, clonal and sanitary selection programs were initiated 10 years ago (Karoglan Kontić et al. 2009a).

The aim of this survey was to obtain additional knowledge about viruses present in autochthonous Croatian grapevine cultivars grown along the coastal region. Because of already confirmed prevalence of GLRaV-3, special attention was given to spatial distribution of its different variant groups. Results provide information that can be used for improving the quality of planting material and implementation of appropriate control measures.

\section{Materials and Methods}

Plant material. Three groups of vines were surveyed: (i) 38 vines of cv. Plavac mali, the most important autochthonous Croatian cultivar; ii) one vine each of cv. Babica, Dobričić, Ljutun, Mladenka, and Vlaška, all from the Kaštela region, considered as the source of numerous autochthonous cultivars; one vine of cv. Dobričić from the island Šolta was added to this group; and (iii) four vines (one each of cv. Jarbola 
and Žlahtina and two of cv. Sansigot) selected from the northern coastal region. The first two groups of samples were taken from a collection located in Zagreb. This collection was established as the byproduct of a clonal selection program and is mainly used for research on grapevine viruses. After a three-year evaluation of agronomic traits (yield, sugar/acid ratio, tolerance to fungal diseases, cluster and berry characteristics) in the original vineyards, cuttings from vines included in clonal selection were taken and self-rooted during 2008 in the current location of the collection. The collection was established on nematode-tested soil and is regularly sprayed for insect vector control to maintain sanitary status of each vine as in the original vineyard. The last group was selected because the vines were showing leaf deformation and mottling symptoms. Three petioles from different sides of each vine were taken and used for total RNA extraction. Samples from the northern coastal region were collected directly from the vineyards during July 2015, while those from the other two groups were taken in the same period but from a plant collection. In total, 48 vines from nine different autochthonous cultivars originating from 23 different locations/vineyards (Fig. 1) were included in the survey and symptoms were monitored. Some of the plants used in this investigation were previously tested for eight viruses by enzyme-linked immunosorbent assay (ELISA) (Vončina et al. 2009, 2012), and Grapevine rupestris stem pitting-associated virus (GRSPaV) by reverse transcription polymerase chain reaction (Vončina et al. 2011a). A summary of those results is available in Supplementary Table S1.

Isolation of total RNA. Total RNA was prepared by grinding $0.1 \mathrm{~g}$ of leaf petiole in liquid nitrogen and extracted using Qiagen RNeasy plant mini kit (Valencia, CA, USA). The modification of original protocol was made by preheating the RLT buffer to $55^{\circ} \mathrm{C}$, dissolving $2.5 \%$ PVP-40 followed by filter sterilization. Purity and integrity of RNA (data not shown) was measured spectrophotometrically (A260/A280 and A260/A230) using NanoPhotometer P330 Spectrophotometer (Implen, München, Germany).

Detection of viruses by quantitative reverse transcription polymerase chain reaction (RT-qPCR). Samples were tested by RTqPCR for a panel of 31 viruses at the University of California, Davis. Tests were conducted using reaction mixtures and cycling conditions described as one-step protocol by Osman et al. (2012). For detection of different viruses, primers and probes were used as described by: Grapevine leafroll-associated virus 2 (GLRaV-2) (Klassen et al. 2011), GRSPaV, GVA, and GFkV (Osman et al. 2008; Osman and Rowhani 2008). For all the other viruses, primers developed at UC Davis were used (Adib Rowhani, unpublished). Viruses included in the survey were: Grapevine leafroll-associated virus (GLRaV) 1, 2, 2 Red Globe, 3, 4, GLRaV-4 strains 5, 6, 9, Pr, Car, GLRaV 7; Arabis mosaic virus (ArMV); Grapevine fanleaf virus (GFLV); Grapevine virus $A, B, D$, $E, F$ (GVA, GVB, GVD, GVE, GVF); GRSPaV; GFkV; Grapevine red globe virus (GRGV); Grapevine Syrah virus-1 (GSyV-1); Grapevine vein feathering virus (GVFV); Grapevine Pinot gris virus (GPGV); Grapevine asteroid mosaic virus (GAMV); Tomato ringspot virus (ToRSV); Tobacco ringspot virus (TRSV); Strawberry latent ringspot virus (SLRV); Blueberry leaf mottle virus (BLMV); Raspberry ringspot virus (RpRSV); Tomato black ring virus (TBRV); and Grapevine deformation virus (GDefV). The positive cycle threshold $(\mathrm{Ct})$ value was set up to 35 with values between 30 and 35 considered as low positive.

Grapevine leafroll-associated virus 3 (GLRaV-3) variant typing. To identify GLRaV-3 specific variants the Qiagen One-Step RT-PCR kit was used following the protocols with fluorescently labeled primers as described by Sharma et al. (2011) for group I, II, III, and IV, and Blaisdell et al. (2015) for group VI. For other variants that may not be identified by the above-mentioned primers, a coat protein $(\mathrm{CP})$ primer set was used (Sharma et al. 2011). PCR products were prepared for fragment analysis as described by Sharma et al. (2011) and submitted to the DNA Sequencing Facility at UC Berkeley. For variant VII, two-step RT-PCR was used according to Maree et al. (2015) with the exception that in cDNA synthesis, virus-specific primers CB19_72F and CB19_1267R (Molenar 2015) were used with the annealing temperature $55^{\circ} \mathrm{C}$ for $30 \mathrm{~s}$. PCR products were visualized on $2 \% 1 \mathrm{X}$ TAE agarose gel previously stained in ethidium bromide. Positive control for variant group VII was the courtesy of Hans J. Maree (Agricultural Research Council, South Africa) and remaining controls were from a greenhouse collection.

Grapevine Pinot gris virus (GPGV). To verify the presence of GPGV in samples positive by RT-qPCR, tests by two-step RT-PCR and DetF/DetR primers (Morelli et al. 2014) were carried out. cDNA was synthesized using $\sim 200 \mathrm{ng}$ of total RNA mixed with $10 \mu \mathrm{M}$ of random hexamers (Thermo Fisher Scientific, Waltham, MA) in total volume of $12 \mu \mathrm{l}$, denatured at $94^{\circ} \mathrm{C}$ for $3 \mathrm{~min}$ followed by $68^{\circ} \mathrm{C}$ for $7 \mathrm{~min}$. The mixture was used for reverse transcription with RevertAid First Strand cDNA synthesis kit (Thermo Scientific) in a 20- $\mu$ l reaction volume consisting of $1 \mathrm{X}$ reaction buffer, $20 \mathrm{U}$ of Ribolock RNease inhibitor, $1 \mathrm{mM}$ of dNTP mix, and 200U of RevertAid M-MuLV reverse transcriptase. Incubation was carried out at $25^{\circ} \mathrm{C}$ for $5 \mathrm{~min}$, followed by $42^{\circ} \mathrm{C}$ for $60 \mathrm{~min}$ and $70^{\circ} \mathrm{C}$ for $5 \mathrm{~min}$. PCR was performed using KAPA Taq PCR kit (KAPA Biosystems, USA) in a 10- $\mu$ l reaction volume consisting of: $1 \mu 1$ cDNA, 1 X KAPA buffer B, $0.2 \mathrm{mM}$ dNTP mix, $1 \mathrm{U}$ of KAPA Taq DNA polymerase, and $0.2 \mu \mathrm{M}$ of each DetF/DetR primer. The mixture was subjected to initial denaturation at $94^{\circ} \mathrm{C}$ for 3 min followed by 35 cycles of denaturation at $94^{\circ} \mathrm{C}$ for $30 \mathrm{~s}$, annealing at $60^{\circ} \mathrm{C}$ for $45 \mathrm{~s}$, and extension at $72^{\circ} \mathrm{C}$ for $1 \mathrm{~min}$. Final extension was carried out at $72^{\circ} \mathrm{C}$ for $7 \mathrm{~min}$ and products were visualized on $2 \% 1 \mathrm{X}$ TAE agarose gel previously stained in ethidium bromide. Amplicons were purified using QIAquick PCR purification kit (Qiagen) and cloned with StrataClone PCR cloning kit (Agilent Technologies, USA) according to manufacturer's instructions. Five cDNA clones per isolate were sequenced in both directions (DNA Sequencing Facility, UC Berkeley) and aligned using MUSCLE program (Tamura et al. 2013) to construct

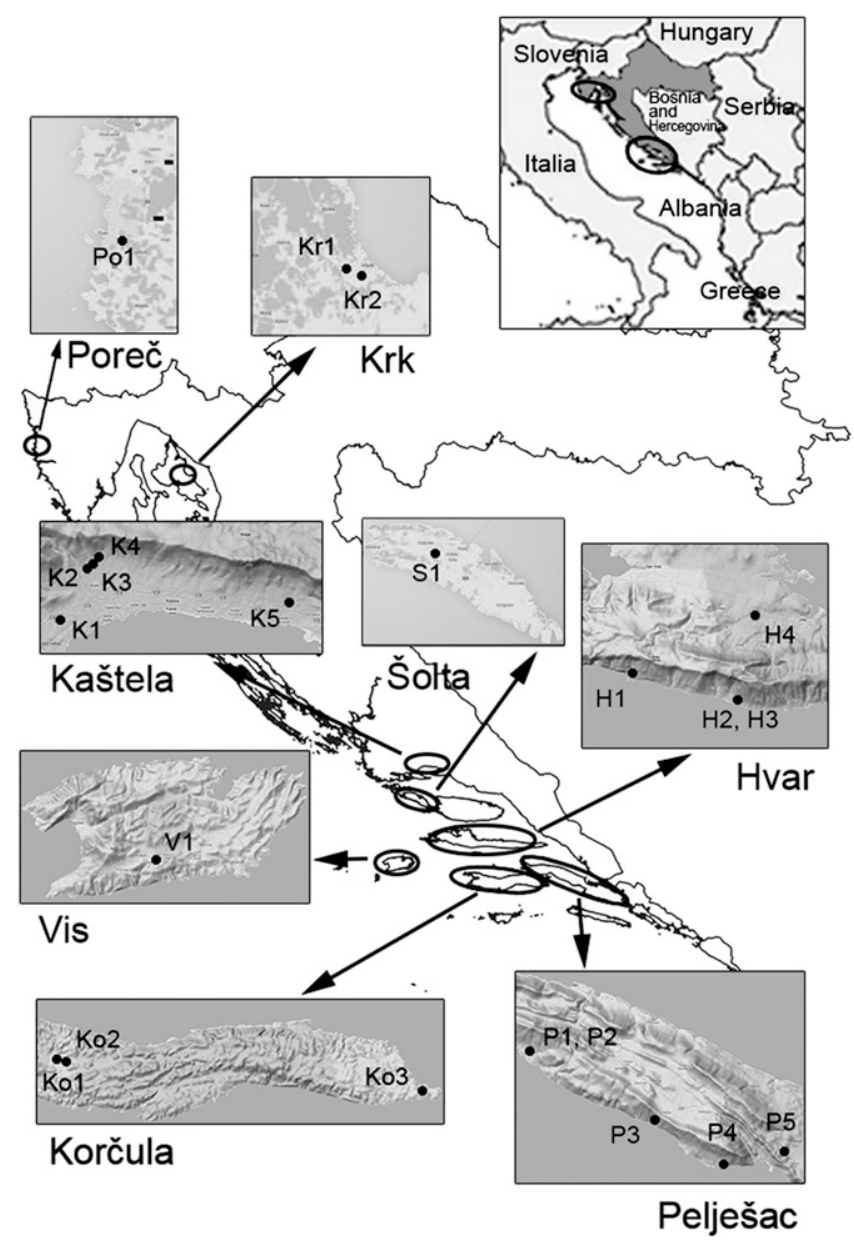

Fig. 1. Locations of vineyards used as a source of material for survey. In total, 48 vines (44 from germplasm collection, 4 from vineyards) from 23 vineyards/locations were tested for presence of viruses using molecular methods. Survey was conducted on nine autochthonous Croatian grapevine cultivars grown along the coastal region. 
consensus sequences that were compared with each other and to GPGV-reference isolate (GenBank Accession No. NC_015782.1). To calculate the best model of nucleotide substitution, MEGA ver. 6 (Tamura et al. 2013) was used and a phylogenetic tree was constructed using maximum likelihood method and 1000 bootstrap replicates. In construction of the phylogenetic tree, sequence data from five symptomatic (FI6AV, ZA-505-5A, BE5A, FI8AV, and ZA(PA)P2; GenBank Accession Nos. LN606710.1, LN606750.1, LN606714.1, LN606708.1, and LN606728.1, respectively) and five symptomless (MOLA 14, Z505-1 N, MOLA 3x3, ZA505-6, SK01 N; GenBank Accession Nos. LN606705.1, LN606749.1, LN606744.1, LN606735.1, and KF134124.1, respectively) GPGV-isolates were used.

Additional one- and two-step RT-PCR tests. In addition to RTqPCR, all samples were tested for the presence of GRSPaV by conventional one-step RT-PCR as described by Rowhani et al. (2000) using the primer pair RSP 48V/49C (Zhang et al. 1998), and by qPCR using cDNA. Two-step RT-PCR was also performed to validate low positive or questionable RT-qPCR results for ArMV, GFLV, GVD, GVF, and GSyV-1. For those tests, cDNA was synthesized as described for GPGV and the following primers were used: CP1202F/CP1313R for ArMV (Osman and Rowhani 2006); 2231/ 2253 for GFLV (Rowhani et al. 1993); and SY5922F/ SY6295R for GSyV-1 (Glasa et al. 2015). For detection of GVD and GVF, primers were designed using available sequences for each virus in the GenBank database: GVD-F 5'-ACCCATCATTTCTCGCAGGT-3' (sense) and GVD-R 5'-TGGCTTTCTTCCTACAGTCAG-3' (antisense) targeting 117-bp fragment of putative RNA binding protein; and GVF-F 5'- GAGGTGGTCGAAACACTGGT-3' (sense) and GVF-R 5'-GGCGTCGAACACTTCTTTGG-3' (antisense) targeting 528-bp fragment of coat protein region. For all five viruses, the following PCR conditions were used: initial denaturation at $94^{\circ} \mathrm{C}$ for $5 \mathrm{~min}$ followed by 35 cycles of denaturation at $94^{\circ} \mathrm{C}$ for $20 \mathrm{~s}$, annealing at $58^{\circ} \mathrm{C}$ for $\mathrm{ArMV}, 54^{\circ} \mathrm{C}$ for $\mathrm{GFLV}, 56^{\circ} \mathrm{C}$ for $\mathrm{GSyV}-1,53^{\circ} \mathrm{C}$ for $\mathrm{GVD}$, and $55^{\circ} \mathrm{C}$ for $\mathrm{GVF}$ for $20 \mathrm{~s}$ and extension at $72^{\circ} \mathrm{C}$ for $30 \mathrm{~s}$. Final extension was carried out at $72{ }^{\circ} \mathrm{C}$ for $10 \mathrm{~min}$. Products were visualized on $2 \% 1 \mathrm{X}$ TAE agarose gel previously stained in ethidium bromide.

\section{Results}

Sanitary status of Croatian vines. The results revealed highest infection rates for GLRaV-3 (91.7\%, determined by RT-qPCR and onestep RT-PCR using CP primers), GVA (91.7\%), GFkV (87.5\%), and GRSPaV ( $83.3 \%$ determined by qPCR using cDNA). Lower occurrence was determined for GLRaV-1 (39.6\%) and GFLV (33.3\% by two-step RT-PCR). GLRaV-2, GLRaV-4-like group (strains 5, 6, and Pr), GVD, GVE, GRGV, GSyV-1, GVFV, GPGV, and GVB were determined in range from 8.3 to $22.9 \%$. Presence of other viruses included in the screening process was not confirmed in any sample (Table 1, Supplementary Tables S2 and S3). The results showed that mixed infections were also common. The most common combinations were GLRaV-3 + GRSPaV and GVA + GRSPaV, GVA + GFkV (91.7\%), GLRaV-3 + GVA (87.5\%), GFkV + GRSPaV (83.3\%), GRSPaV + GFkV, and GLRaV-3 + GFkV (83.3\%). In 79.2\% of vines, simultaneous infection with GLRaV-3 + GVA + GFkV + GRSPaV was confirmed. No virusfree vine was found, and the number of viruses present in a single vine ranged from three (vine accessions PMC-003, PMC-011, and PMC313) up to nine (vine accession VD-102). Downward rolling of leaf margins and premature reddening were observed in late summer on vines infected with viruses from the leafroll complex.

GLRaV-3 variants. The GLRaV-3 variant group most frequently found was group II $(77.3 \%)$, followed by group I (65.9\%) and group III (4.6\%). Variants from other groups were not detected. In cv. Plavac mali, group II was detected in 30 (85.7\%) of GLRaV-3 positive vines, group I in $21(60 \%)$, and mixed infections with both variants were present in 17 (48.6\%) vines. Cultivar Dobrinčić from the island Šolta showed to be infected only with variant group II. Kaštela region vines were infected with group I ( 5 vines out of 5 ), followed by group II ( 3 out of 5). This was the only region where group III ( 2 out of 5) was detected. In the northern coastal region (cvs. Jarbola, Sansigot, and Žlahtina), only group I (3 out of 4) was found (Table 1).

GPGV. Four vines with symptoms of leaf deformations and mottling from the northern coastal region (cvs. Jarbola, Sansigot, and Žlahtina) were positive for GPGV. In the 2015 and 2016 growing seasons, described symptoms were evident on all plants in the period from the early stage of growth up to the start of blossoming. The most severe symptoms were observed on cv. Jarbola. Sequence analyses comprising part of movement protein (MP) and coat protein (CP) genes (549 nt) showed that isolates K1 (cv. Žlahtina) and K2 (cv. Sansigot) were identical, while isolate K4 (cv. Jarbola) showed $97.5 \%$ similarity with isolates K1/K2 (14 nucleotide differences, 10 in MP, and 6 in CP region). Croatian isolates shared $95.9 \%$ and $98.5 \%$ similarity at amino acid level for partial MP and CP, respectively. Compared with reference isolate NC_015782, all Croatian isolates shared 97.1\% nucleotide similarity with 16 nucleotide differences: 13 in MP region; and 5 (K1/K2) and 7 (K4) in $\mathrm{CP}$ region. At the amino acid level, similarity with the

Table 1. Results of molecular tests (RT-qPCR, qPCR-cDNA, one- and two-step RT-PCR) done on autochthonous Croatian grapevine cultivars grown in coastal region. Data are shown only for viruses confirmed in at least one vine/sample.

\begin{tabular}{|c|c|c|c|c|c|c|c|c|c|}
\hline \multirow[b]{2}{*}{ Region } & \multirow[b]{2}{*}{ Cultivar(s) ${ }^{\mathrm{x}}$} & \multirow[b]{2}{*}{$\begin{array}{c}\text { Vineyard location(s) } \\
\text { (see Fig. 1) }\end{array}$} & \multirow[b]{2}{*}{$\begin{array}{c}\text { No. of } \\
\text { analyzed vines }\end{array}$} & \multirow[b]{2}{*}{ GLRaV-1 } & \multirow[b]{2}{*}{ GLRaV-2 } & \multicolumn{4}{|c|}{ GLRaV-3 } \\
\hline & & & & & & Variant I & Variant II & Variant III & $\begin{array}{c}\text { RT-qPCR } \\
\& \text { C } P^{y}\end{array}$ \\
\hline Vis & PM & V1 & 6 & 0 & 0 & 1 & 5 & 0 & 5 \\
\hline \multirow[t]{3}{*}{ Korčula } & & Ko3 & 2 & 2 & 0 & 2 & 2 & 0 & 2 \\
\hline & & Ko2 & 2 & 0 & 0 & 1 & 2 & 0 & 2 \\
\hline & & Ko1 & 2 & 1 & 0 & 0 & 2 & 0 & 2 \\
\hline \multirow[t]{5}{*}{ Pelješac } & & P5 & 3 & 2 & 0 & 2 & 0 & 0 & 3 \\
\hline & & P4 & 4 & 1 & 0 & 3 & 3 & 0 & 4 \\
\hline & & P1 & 1 & 1 & 0 & 1 & 1 & 0 & 1 \\
\hline & & P2 & 1 & 1 & 0 & 0 & 1 & 0 & 1 \\
\hline & & P3 & 1 & 1 & 0 & 0 & 1 & 0 & 1 \\
\hline \multirow[t]{4}{*}{ Hvar } & & $\mathrm{H} 2$ & 3 & 1 & 2 & 2 & 3 & 0 & 3 \\
\hline & & $\mathrm{H} 1$ & 4 & 1 & 1 & 3 & 3 & 0 & 3 \\
\hline & & $\mathrm{H} 3$ & 3 & 3 & 0 & 2 & 2 & 0 & 2 \\
\hline & & $\mathrm{H} 4$ & 6 & 2 & 1 & 4 & 5 & 0 & 6 \\
\hline Šolta \& Kaštela Region & $\mathrm{B}, \mathrm{D}, \mathrm{LJ}, \mathrm{M}, \mathrm{V}$ & S1 \& K1-K5 & 6 & 3 & 0 & 5 & 4 & 2 & 6 \\
\hline \multirow[t]{4}{*}{ Northern Coast } & $\mathrm{J}, \mathrm{S}, \check{\mathrm{Z}}$ & Po1, Kr1-2 & 4 & 0 & 0 & 3 & 0 & 0 & 3 \\
\hline & Total & 23 & 48 & 19 & 4 & 29 & 34 & 2 & 44 \\
\hline & $\%$ & & & 39.6 & 8.3 & 60.4 & 70.8 & 4.2 & 91.7 \\
\hline & & & & & & & & \multicolumn{2}{|c|}{ (continued on next page } \\
\hline
\end{tabular}

x Cultivar abbreviations: PM = Plavac mali; B = Babica; D = Dobričić; LJ = Ljutun; M = Mladenka; V = Vlaška; J = Jarbola; S = Sansigot; $\check{Z}=$ Žlahtina.

y For GLRaV-3 RT-qPCR and one-step RT-PCR using CP primers gave identical results.

${ }^{\mathrm{z}}$ For GRSPaV qPCR results using cDNA are shown, as method with largest number of positive samples. 
reference isolate was $95.2 \%(\mathrm{~K} 1 / \mathrm{K} 2)$ and $93.9 \%(\mathrm{~K} 4)$ for $\mathrm{MP}$, and $97 \%$ (K1/K2) and $98.5 \%$ (K4) for CP. Phylogenetic analysis clustered all Croatian isolates within the "symptomatic group" (Fig. 2). Sequences of all Croatian GPGV isolates mentioned in this paper are deposited in GenBank with Accession Nos. KX518622 (K1), KX518621 (K2), and KX518620 (K4).

\section{Discussion}

This survey confirmed high infection rates with several economically important viruses in autochthonous Croatian grapevine cultivars. Presence of GLRaV-3, GVA, GFkV and GRSPaV was confirmed in almost all vines originating from 23 different vineyards. GRSPaV, although present in most of the vines $(77.1 \%$ determined by end-point RT-PCR, $83.3 \%$ by qPCR-cDNA) is considered a less harmful virus (Gambino et al. 2012). A significant difference in disease prevalence was determined for GFkV (87.5\%), which was in previous investigations reported in up to $36.8 \%$ of analyzed samples (Vončina et al. 2011b). When compared with previous ELISA results, the significantly larger number of vines positive for GFkV with molecular methods was probably a consequence of monoclonal antibodies used in ELISA and the increased sensitivity of molecular detection (Table 1). The GFkV vector is still unknown, but some observations in Italy (Fortusini et al. 1996), South Africa (Engelbrecht and Kasdorf 1990), and Japan (Yamakawa, 1989) suggest the possibility of natural spread. The larger number of vines infected with other viruses in the collection (GFLV from 13 to 15, GLRaV-1 from 14 to 19, GLRaV-2 from 2 to 4, GVA from 30 to 42 , and GVB from 6 to 8 ) is partially a consequence of the detection methods used (serological vs. molecular), and potentially due to natural spread of viruses over the seven-year period after establishment. In the case of GFLV, as vines PMC-178 (ELISA 2008 and RT-PCR positive), PMC-181 (ELISA 2007 negative, RT-PCR positive), PMC-236 (ELISA 2007 and RT-PCR positive), and PMC-235 (ELISA 2007 negative, RT-PCR positive) were planted next to each other in the collection, it is possible that local spread occurred. Twostep RT-PCR results (Supplementary Fig. S1) for ArMV and GFLV were more similar to ELISA results than RT-qPCR results. Differences in ELISA and molecular test results for GLRaV-1, 2, 3, GVA, and GVB may be due to sampling period, lower sensitivity of ELISA, and use of monoclonal antibodies (GVA, GVB) since more positive samples were detected by molecular tests. Although the plant collection was regularly sprayed with insecticides, the possibility for vector transmission of some of the viruses in the seven-year period cannot be ignored.
A significant difference in sensitivity of GRSPaV detection by different molecular methods was observed. The number of positive samples was the lowest using RT-qPCR (nine), while use of one-step PCR and qPCR-cDNA resulted in 26 and 29 additional positive samples, respectively. Two vines positive for GRSPaV when tested by RT-qPCR were not positive using other two methods. In addition, samples with RT-qPCR results for GVD, GVF, and GSyV-1 initially classified as low positive, were positive (except two samples of GVD) with detection by two-step RT-PCR. Since the same RNA was used in all molecular tests, it is possible that primer and probe design may play a role in different results and detection efficiency. Molecular detection methods, developed over the last few decades, target specific pathogens (or closely related groups) and often are not effective in detecting pathogens that are genetically different to those already described. In such cases, preference should be given to nontargeted methods (like next generation sequencing). Those methods may allow detection and identification of pathogens without or with very limited prior knowledge about their genomes.

Common mixed infections were detected in vines prior to establishment of the collection used here, and are probably the result of the common practice of vegetative propagation without adequate clonal selection and sanitary control. Simultaneous infections, especially with viruses belonging to infective degeneration, leafroll, and rugose wood complex, often have synergistic effect leading to more severe plant damage (Martelli and Boudon-Padieu 2006).

GLRaV-3 variant typing confirmed the prevalence of variant groups I and II. The same groups were dominant in Portugal (Gouveia et al. 2011). Prevalence of variant group II is reported from South Africa (Jooste et al. 2011), Spain (Pesqueira et al. 2016), and Hungary (Cseh et al. 2013), while Napa Valley (Sharma et al. 2011), China (Farooq et al. 2012), and New Zealand (Chooi et al. 2013) are dominated by group I. Mixed infections with both variants were present in 20 GLRaV-3 positive vines (45.5\%), significantly more than the $25.3 \%$ reported from Portugal (Gouveia et al. 2011) or 22\% from Napa Valley (Sharma et al. 2011). Our study had a much smaller sample size than studies in Portugal and Napa Valley; therefore, reliable comparisons are difficult to make. Also, our study did not include all known GLRaV-3 variants such as group VI-like (Maree et al. 2015) and mild strains reported from Australia (Rast et al. 2012). It is possible that other GLRaV-3 variants are present in Croatia and that mixed infections are more common than determined here. Besides planting material, GLRaV-3 is spread in the field by various species of mealybugs (Pseudococcidae) and some soft-scale insects (Coccidae) in a

Table 1. (continued from preceding page)

\begin{tabular}{|c|c|c|c|c|c|c|c|c|c|c|c|c|c|}
\hline $\begin{array}{l}\text { GLRaV-4 } \\
\text { like group }\end{array}$ & ArMV & GFLV & GVA & GVB & GVD & GVE & GVF & $\operatorname{GRSPaV}^{z}$ & GFkV & GRGV & GSyV-1 & GVFV & GPGV \\
\hline 1 & 0 & 0 & 4 & 3 & 0 & 0 & 1 & 5 & 4 & 1 & 1 & 1 & 0 \\
\hline 0 & 1 & 0 & 2 & 0 & 0 & 0 & 0 & 1 & 1 & 0 & 0 & 0 & 0 \\
\hline 0 & 1 & 1 & 2 & 1 & 0 & 0 & 0 & 2 & 1 & 1 & 0 & 0 & 0 \\
\hline 0 & 0 & 0 & 2 & 0 & 0 & 0 & 0 & 2 & 2 & 0 & 0 & 1 & 0 \\
\hline 0 & 1 & 0 & 3 & 0 & 0 & 0 & 1 & 3 & 1 & 2 & 0 & 2 & 0 \\
\hline 1 & 2 & 2 & 4 & 2 & 0 & 0 & 0 & 4 & 2 & 1 & 2 & 2 & 0 \\
\hline 0 & 1 & 0 & 1 & 0 & 1 & 0 & 1 & 1 & 1 & 0 & 0 & 0 & 0 \\
\hline 0 & 1 & 1 & 1 & 0 & 1 & 0 & 1 & 1 & 1 & 0 & 0 & 0 & 0 \\
\hline 0 & 1 & 1 & 1 & 0 & 1 & 0 & 1 & 0 & 0 & 0 & 0 & 0 & 0 \\
\hline 0 & 3 & 2 & 3 & 0 & 0 & 1 & 0 & 2 & 1 & 0 & 0 & 1 & 0 \\
\hline 0 & 3 & 0 & 4 & 0 & 0 & 0 & 1 & 3 & 3 & 0 & 1 & 1 & 0 \\
\hline 0 & 2 & 2 & 3 & 0 & 0 & 0 & 0 & 2 & 2 & 0 & 0 & 0 & 0 \\
\hline 2 & 6 & 2 & 6 & 0 & 0 & 0 & 0 & 4 & 4 & 0 & 0 & 0 & 0 \\
\hline 1 & 5 & 4 & 6 & 2 & 4 & 1 & 5 & 6 & 5 & 0 & 0 & 0 & 0 \\
\hline 0 & 4 & 1 & 2 & 2 & 0 & 2 & 0 & 4 & 4 & 1 & 0 & 3 & 4 \\
\hline 5 & 30 & 16 & 44 & 10 & 7 & 4 & 11 & 40 & 42 & 6 & 4 & 11 & 4 \\
\hline 10.4 & 62.5 & 33.3 & 91.7 & 20.8 & 14.6 & 8.3 & 22.9 & 83.3 & 87.5 & 12.5 & 8.3 & 22.9 & 8.3 \\
\hline
\end{tabular}




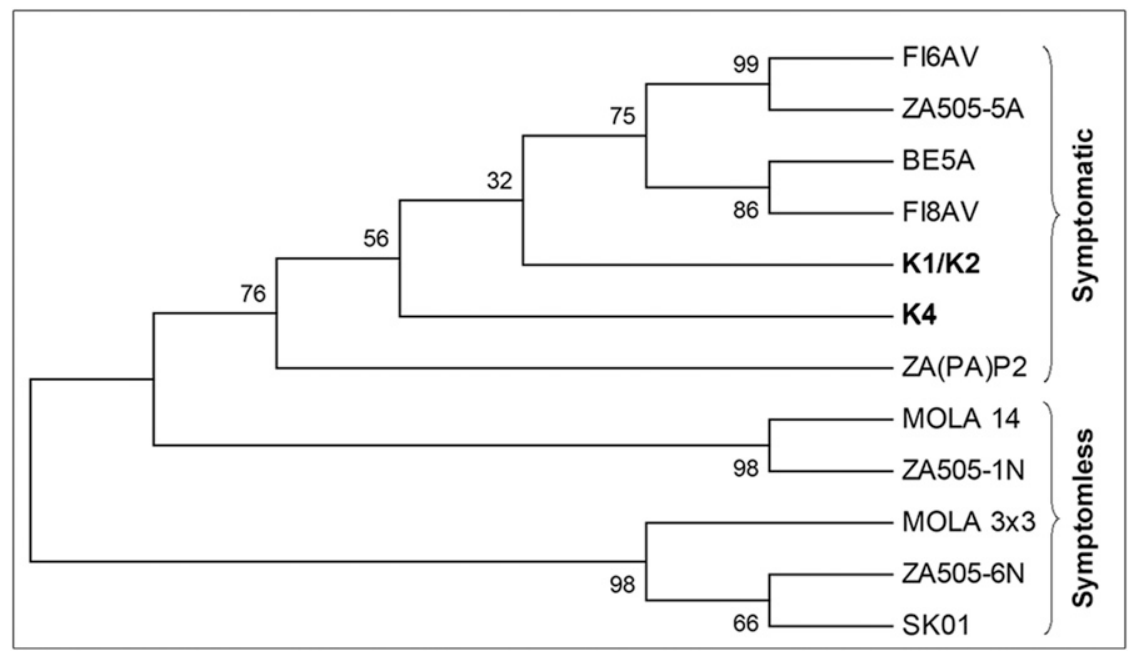

Fig. 2. Phylogenetic tree constructed by MEGA 6 program using maximum likelihood method and 1000 bootstrap replicates. GPGV genome movement and coat protein genes (549 nt) were used for construction of the tree. Croatian GPGV isolates are marked with K1 (cv. Žlahtina), K2 (cv. Sansigot), and K4 (cv. Jarbola). Ten other GPGV isolates from GenBank were used as representatives of "symptomatic" and "symptomless groups." Results revealed that all Croatian GPGV isolates clustered within "symptomatic group."

semipersistent manner (Tsai et al. 2008, 2010). Vectors are considered as the major factor responsible for introduction and spread of GLRaV3 in newly established, healthy vineyards (Maree et al. 2013; Almeida et al. 2013). Masten Milek (2007) reported several insect species present in Croatia that are capable of transmission of different viruses: Neopulvinaria innumerabilis (GLRaV-1, GLRaV-3, GVA); Parthenolecanium corni (GLRaV-1, GVA); Pulvinaria vitis (GLRaV-1, GLRaV3); Phenacoccus aceris (GLRaV-1, GLRaV-3); Planococcus citri (GLRaV-3, GVA); P. ficus (GLRaV-1, GLRaV-3, GVA); and Pseudococcus viburni (GLRaV-3). Phenacoccus aceris, Planococcus citri, Parthenolecanium corni, and $N$. innumerabilis were reported by Maceljski (1999) as significant grapevine pests in Croatia. Their role in virus spread under Croatian environmental conditions is unknown, but it is expected that they are vectors (Tsai et al. 2010).

GPGV was recently reported from different European countries (Bertazzon et al. 2015; Beuve et al. 2015; Martelli 2014b; Mavrič Pleško et al. 2014), the United States (Al Rwahnih et al. 2016), Canada (Xiao et al. 2016), China (Fan et al. 2015), and South Korea (Cho et al. 2013). After the first report from Croatia by Bertazzon et al. (2015), this study provides partial genomic data for isolates originating from autochthonous Croatian grapevine cultivars. According to the phylogenetic analysis and classification proposed by Saldarelli et al. (2015), all Croatian isolates belong to the symptom-associated phylogenetic clade (Fig. 2). Since all GPGV-infected vines were multiply infected, it was not possible to connect disease symptoms to GPGV alone. According to Bertazzon et al. (2016), expression of symptoms is not correlated only with GPGV variants, but also with virus populations; symptomatic vines have significantly higher virus populations when compared with symptomless vines.

To the best of our knowledge, the presence of seven viruses (multiple strains of GLRaV-4, GVD, GVE, GVF, GRGV, GSyV-1, and GVFV) was confirmed for the first time in Croatia. Although viruses from the GLRaV-4 group are transmitted by mealybugs, they are considered less important when compared with GLRaV-3 (Maree et al. 2013). GRGV is disseminated through grafting and propagation material, causing symptomless infections (Martelli et al. 2002). GSyV-1, reported also as Grapevine virus Q (GVQ) from muscadine grapes and blackberries (Sabanadzovic et al. 2009) and in grapevines from different countries (Al Rwahnih et al. 2009; Engel et al. 2010; Giampetruzzi et al. 2012; Glasa et al. 2015; Oosthuizen et al. 2016), is widespread with as-yet limited data on its effect on grapevine production and interaction with other viruses. Two more recently discovered members of the genus Vitivirus (GVE and GVF), in which some members cause wood-marking abnormalities (e.g., GVA and GVB), were also found in this survey. More detailed investigation of this group of Croatia's newly discovered viruses, including additional confirmation tests, will be undertaken if specific symptoms or negative impacts are recorded on infected vines.

\section{Acknowledgments}

We thank Kai Blaisdell and Anne Sicard for help and assistance in laboratory work and Kristina Diklić for field observations. Special thanks to Hano J. Maree and Rachelle Bester for constructive suggestions and for providing GLRaV-3 variant group VII positive control.

The research leading to these results has received funding from Foundation Plant Services and the European Union Seventh Framework Program (FP7 2007-2013) under grant agreement no. 291823 Marie Curie FP7-PEOPLE-2011COFUND (The New International Fellowship Mobility Program for Experienced Researchers in Croatia - NEWFELPRO). This article has been prepared as a part of a project "Ecology of an emerging grapevine virus in Croatia and California (EcoGVCC)" which has received funding through NEWFELPRO project under grant agreement no. 51 .

\section{Literature Cited}

Al Rwahnih, M., Daubert, S., Golino, D., and Rowhani, A. 2009. Deep sequencing analysis of RNAs from a grapevine showing Syrah decline symptoms reveals a multiple virus infection that includes a novel virus. Virology 387:395-401

Al Rwahnih, M., Golino, D., and Rowhani, A. 2016. First report of Grapevine Pinot gris virus infecting grapevine in the United States. Plant Dis. 100:1030

Almeida, R. P. P., Daane, K. M., Bell, V. A., Blaisdell, G. K., Cooper, M. L., Herrbach, E., and Pietersen, G. 2013. Ecology and management of grapevine leafroll disease. Front. Microbiol. 4:94.

Batović, Š., and Kukoč, Š. 1987. Grobni humak iz ranog Brončanog Doba u Podvršju. Rad. Filoz. Fak. 27:5-68.

Bertazzon, N., Filippin, L., Forte, V., and Angelini, E. 2015. Grapevine Pinot gris virus seems to have recently been introduced to vineyards in Veneto, Italy. Arch. Virol. 161:711-714.

Bertazzon, N., Forte, V., Filippin, L., Causin, R., Maixner, M., and Angelini, E. 2016. Association between genetic variability and titre of the Grapevine Pinot gris virus with disease symptoms. Plant Pathol. doi:10.1111/ppa.12639

Beuve, B., Candresse, T., Tannieres, M., and Lemaire, O. 2015. First report of Grapevine Pinot gris virus (GPGV) in grapevine in France. Plant Dis. 99:293.

Blaisdell, G. K., Zhang, S., Bratburd, J. R., Daane, K. M., Cooper, M. L., and Almeida, R. P. P. 2015. Interactions within susceptible hosts drive establishment of genetically distinct variants of an insect-borne pathogen. J. Econ. Entomol. 108:1531-1539.

Cho, I. S., Jung, S. M., Cho, J. D., Choi, G. S., and Lim, H. S. 2013. First report of Grapevine pinot gris virus infecting grapevine in Korea. New Dis. Rep. 27:10.

Chooi, K. M., Cohen, D., and Pearson, M. N. 2013. Generic and sequence-variants pecific molecular assays for the detection of the highly variable Grapevine leafroll-associated virus 3. J. Virol. Methods 189:20-29.

Cseh, E., Takács, A. P., Gáborjányi, R., Palkovics, L., and Kocsis, L. 2013. RTPCR analysis and evolutionary relationship of some Hungarian Grapevine leafroll associated virus 1 and 3 isolates. Am. J. Plant Sci. 4:2006-2010.

Engel, E. A., Rivera, P. A., and Valenzuela, P. D. T. 2010. First report of Grapevine Syrah virus-1 in Chilean grapevines. Plant Dis. 94:633. 
Engelbrecht, D. J., and Kasdorf, G. G. F. 1990. Field spread of corky bark, fleck, leafroll and Shiraz decline diseases and associated viruses in South African grapevines. Phytophylactica 22:347-354.

Fan, X. D., Dong, Y. F., Zhang, Z. P., Ren, F., Hu, G. H., Li, Z. N., and Zhou, J. 2016. First report of Grapevine pinot gris virus in grapevines in China. Plant Dis. 100:540.

Farooq, A. B. U., Ma, Y., Wand, Z., Zhou, N., and Wenxing, X. 2013. Genetic diversity analyses reveal novel recombination events in Grapevine leafrollassociated virus 3 in China. Virus Res. 171:15-21.

Fortusini, A., Scattini, G., Cinquanta, S., and Prati, S. 1996. Diffusione naturale del virus 1 (GLRaV-1) e del virus 3 (GLRaV-3) dell'accartocciamento fogliare e del virus della maculatura infettiva o "fleck" (GFkV) della vite. Inf. Fitopatol. 46:39-43.

Fuller, K. B., Alston, J. M., and Golino, D. A. 2015. The economic benefits from virus-screening: A case study of grapevine leafroll in the North Coast of California. Am. J. Enol. Vitic. 66:112-119.

Gale, G. 2003. Saving the vine from Phylloxera: a never-ending battle. Pages 70-91 in: Wine: A Scientific Exploration. M. Sandler, and R. Pinder, eds. Taylor \& Francis, New York, NY.

Gambino, G., Cuozzo, D., Fasoli, M., Pagliarani, C., Vitali, M., Boccacci, P., Pezzotti, M., and Mannini, F. 2012. Co-evolution between Grapevine rupestris stem pittingassociated virus and Vitis vinifera $\mathrm{L}$. leads to decreased defense responses and increased transcription of genes related to photosynthesis. J. Exp. Bot. 63:5919-5933.

Giampetruzzi, A., Roumi, V., Roberto, R., Malossini, U., Yoshikawa, N., La Notte, P., Terlizzi, F., Credi, R., and Saldarelli, P. 2012. A new grapevine virus discovered by deep sequencing of virus- and viroid-derived small RNAs in cv. Pinot gris. Virus Res. 163:262-268.

Glasa, M., Predajna, L., Soltys, K., Sabanadzovic, S., and Olmos, A. 2015. Detection and molecular characterisation of Grapevine Syrah virus-1 isolates from Central Europe. Virus Genes 51:112-121.

Gouveia, P., Santos, M. T., Eiras-Dias, J. E., and Nolasco, G. 2011. Five phylogenetic groups identified in the coat protein gene of Grapevine leafrollassociated virus 3 obtained from Portuguese grapevine varieties. Arch. Virol. 156:413-420.

Hull, R. 2002. Matthews' Plant Virology, 4th Ed. Elsevier Ltd., London, UK.

Jooste, A. E. C., Pietersen, G., and Burger, J. T. 2011. Distribution of Grapevine leafroll-associated virus 3 variants in South African vineyards. Eur. J. Plant Pathol. 131:371-381

Karoglan Kontić, J., Pejić, I., Maletić, E., Sladonja, B., Poljuha, D., Vokurka, A., Zdunić, G., Preiner, D., Šimon, S., and Ruehl, E. 2009a. Virus diseases screening in clonal selection of Croatian grapevine cultivars. Acta Hortic. 827:623-626.

Karoglan Kontić, J., Preiner, D., Šimon, S., Zdunić, G., Poljuha, D., and Maletić, E. 2009b. Sanitary status of Croatian native grapevine varieties. Agric. Conspectus Scientificus 74:99-103.

Klaassen, V. A., Sim, S. T., Dangl, G. S., Osman, F., Al Rwahnih, M., Rowhani, A., and Golino, D. A. 2011. Vitis californica and Vitis californica $\times$ Vitis vinifera hybrids are hosts for Grapevine leafroll-associated virus-2 and -3 , and Grapevine virus $A$ and B. Plant Dis. 95:657-665.

Maceljski, M. 1999. Poljoprivredna Entomologija. Zrinski, Čakovec, Croatia.

Malagnini, V., de Lillo, E., Saldarelli, P., Beber, R., Duso, C., Raiola, A., Zanotelli, L., Valenzano, D., Giampetruzzi, A., Morelli, M., Ratti, C., Causin, R., and Gualandri, V. 2016. Transmission of grapevine Pinot gris virus by Colomerus vitis (Acari:Eriophyidae) to grapevine. Arch. Virol. 161:2595-2599.

Maletić, E., Karoglan Kontić, J., Pejić, I., Preiner, D., and Šimon, S. 2007. Grapevine genetic resources in Croatia: Preservation, evaluation and revitalization of autochthonous varieties. Pages 166-167 in: Conference on Native Breeds and Varieties as part of Natural and Cultural Heritage, November 13-16 2007, Sibenik, Croatia.

Maletić, E., Karoglan Kontić, J., Pejić, I., Preiner, D., Zdunić, G., Bubola, M., Stupić, D., Andabaka, Ž., Marković, Z., Šimon, S., Žulj Mihaljević, M., Ilijaš, I., and Marković, D. 2015. Green Book: Indigenous Grapevine Varieties of Croatia. State Institute for Nature Protection, Croatia.

Maliogka, V. I., Martelli, G. P., Fuchs, M., and Katis, N. I. 2015. Control of viruses infecting grapevine. Control of Plant Virus Diseases Vegetatively-Propagated Crops. Adv. Virus Res. 91:175-227.

Maree, H. J., Almeida, R. P., Bester, R., Chooi, K. M., Cohen, D., Dolja, V. V., Fuchs, M. F., Golino, D. A., Jooste, A. E., Martelli, G. P., Naidu, R. A., Rowhani, A., Saldarelli, P., and Burger, J. T. 2013. Grapevine leafrollassociated virus 3. Front. Microbiol. 16:82.

Maree, H. J., Pirie, M. D., Oosthuizen, K., Bester, R., Rees, D. J. G., and Burger, J. T. 2015. Phylogenomic analysis reveals deep divergence and recombination in an economically important grapevine virus. PLoS One 10:e0126819.

Martelli, G. P. 2014a. Grapevine infecting-viruses: Directory of virus and viruslike diseases of the grapevine and their agents. J. Plant Pathol. 96:S7-S8.

Martelli, G. P. 2014b. Directory of virus and virus-like diseases of the grapevine and their agents. J. Plant Pathol. 96:S105-S120.

Martelli, G. P., and Boudon-Padieu, E. 2006. Directory of infectious diseases of grapevines and viroses and virus-like diseases of the grapevine: Bibliographic report 1998-2004. Options Méditerranéennes, Série B, no. 55. Centre International de Hautes Etudes Agronomiques Méditerranéennes, Bari, Italy.

Martelli, G. P., Sabanadzovic, S., Abou Ghanem-Sabanadzovic, N., and Saldarelli, P. 2002. Maculavirus, a new genus of plant viruses. Arch. Virol. 147:1847-1853.

Masten Milek, T. 2007. Fauna štitastih uši (Insecta: Coccoidea) u Republici Hrvatskoj. PhD thesis. Josip Juraj Strossmayer University of Osijek, Croatia.
Molenaar, N. 2015. Determination of the virus diversity associated with grapevine leafroll disease. Master thesis, Stellenbosch University, South Africa.

Morelli, M., de Moraes Catarino, A., Susca, L., Saldarelli, P., Gualandri, V., and Martelli, G. P. 2014. First report of Grapevine Pinot gris virus from table grapes in Southern Italy. J. Plant Pathol. 96:439.

Oosthuizen, K., Coetzee, B., Maree, H. J., and Burger, J. T. 2016. First Report of Grapevine Syrah virus 1 in South African Grapevines. Plant Dis. 100:1252.

Osman, F., Leutenegger, C., Golino, D., and Rowhani, A. 2008. Comparison of low-density arrays, RT-PCR and real-time TaqMan RT-PCR in detection of grapevine viruses. J. Virol. Methods 149:292-299.

Osman, F., Olineka, T., Hodzic, E., Golino, D., and Rowhani, A. 2012. Comparative procedures for sample processing and quantitative PCR detection of grapevine viruses. J. Virol. Methods 179:303-310.

Osman, F., and Rowhani, A. 2006. Application of a spotting sample preparation technique for the detection of pathogens in woody plants by RT-PCR and real-time PCR (TaqMan). J. Virol. Methods 133:130-136.

Osman, F., and Rowhani, A. 2008. Real-time RT-PCR (TaqMan) assays for the detection of viruses associated with Rugose wood complex of grapevine. J. Virol. Methods 154:69-75.

Pearson, R. C., and Goheen, A. C. 1988. Compendium of Grape Diseases. American Phytopathological Society, St. Paul, MN.

Pesqueira, A. M., Cabaleiro, C., and Velasco, L. 2016. Genetic analysis of Grapevine leafroll-associated virus 3 population from Galicia, Spain. Plant Pathol. 65:310-321.

Poljuha, D., Sladonja, B., and Bubola, M. 2010. Incidence of viruses infecting grapevine varieties in Istria (Croatia). J. Food Agric. Environ. 8:166-169.

Pouget, R. 1988. Vitis vinifera, histoire et évolution. Pages 15-25 in: La Vigne et le Vin. La Manufacture et la Cite'des sciences et de l'industrie (eds.), Graficas.

Rast, H. E., James, D., Habili, N., and Masri, S. A. 2012. Genome organization and characterization of a novel variant of Grapevine leafroll-associated virus 3. Page 61-62 in: Proceedings of the 17th Congress of ICVG, 7-14 October 2012, Davis, CA

Rowhani, A., Chay, C., Golino, D. A., and Falk, B. W. 1993. Development of polymerase chain reaction technique for the detection of grapevine fanleaf virus in grapevine tissue. Phytopathology 83:749-753.

Rowhani, A., Zhang, Y. P., Chin, J., Minafra, A., Golino, D. A., and Uyemoto, J. K. 2000. Grapevine rupestris stem pitting associated virus: population diversity, titer in the host, and possible transmission vector. Page 37 in: Proceedings of the 13th Meeting ICVG, 12-17 March 2000, Adelaide, Australia

Sabanadzovic, S., Ghanem-Sabanadzovic, N. A., and Gorbalenya, A. E. 2009. Permutation of the active site of putative RNA-dependent RNA polymerase in a newly identified species of plant alpha-like virus. Virology 394:1-7.

Saldarelli, P., Giampetruzzi, A., Morelli, M., Malossini, U., Pirolo, C., Bianchedi, P., and Gualandri, V. 2015. Genetic variability of Grapevine Pinot gris virus and its association with grapevine leaf mottling and deformation. Phytopathology 105:555-563.

Sarić, A., and Corte, A. 1959. Sintomatologia della degenerazione infetiva della vite in Istria. Atti Ist. Bot. Lab. Crit Univ. Pavia 17:3-8.

Sharma, A. M., Wang, J., Duffy, S., Zhang, S., Wong, M. K., Rashed, A., Cooper, M. L., Daane, K. M., and Almeida, R. P. P. 2011. Occurrence of Grapevine leafroll-associated virus complex in Napa Valley. PLoS One 6:e26227.

Tamura, K., Stecher, G., Peterson, D., Filipski, A., and Kumar, S. 2013. MEGA6: Molecular Evolutionary Genetics Analysis, version 6.0. Mol. Biol. Evol. 30: 2725-2729.

Topolovec-Pintarić, S. 1990. Analize vinove loze na prisustvo virusa Elisa metodom u rasadniku Jastrebarsko (Mladina). Master's thesis. Faculty of Agriculture, University of Zagreb, Croatia

Tsai, C. W., Chau, J., Fernandez, L., Bosco, D., Daane, K. M., and Almeida, R. P. P. 2008. Transmission of Grapevine leafroll-associated virus 3 by the vine mealybug (Planococcus ficus). Phytopathology 98:1093-1098.

Tsai, C. W., Rowhani, A., Golino, D. A., Daane, K. M., and Almeida, R. P. P. 2010. Mealybug transmission of grapevine leafroll viruses: an analysis of virus-vector specificity. Phytopathology 100:830-834

Vončina, D., Badurina, D., Preiner, D., Cvjetković, B., Maletić, E., and Karoglan Kontic, J. 2011b. Incidence of virus infections in grapevines from Croatian collection plantations. Phytopathol. Mediterr. 50:316-326.

Vončina, D., Đermić, E., Cvjetković, B., Maletić, E., Pejić, I., and Karoglan Kontić, J. 2009. Occurrence of the important grapevine viruses in population of Croatian autochthonous grapevine varieties from Kaštela region. Pages 199-200 in: 32nd World Congress of Vine and Wine, 7th General Assembly of the OIV and Wine, 28 June - 3 July 2009, Zagreb, Croatia.

Vončina, D., Jurić, S., Šimon, S., Cvjetković, B., Fulgosi, H., and Pejić, I. 2011a Detection and partial molecular characterization of Grapevine rupestris stem pitting-associated virus in Croatia. Pages 250-251 in: 46th Croatian \& 6th International Symposium on Agriculture, 14-18 February 2011, Opatija, Croatia.

Vončina, D., Preiner, D., Radović, D., Maletić, E., and Karoglan Kontić, J. 2012 Prevalence of viruses in autochthonous grapevine cultivars from Croatian continental and coastal vine-growing regions. Pages 221-225 in: International Symposium on Current Trends in Plant Protection, 25-28 September 2012, Belgrade, Serbia.

Xiao, H., Shabanian, M., McFadden-Smith, W., and Meng, B. 2016. First report of Grapevine Pinot gris virus in commercial grapevines in Canada. Plant Dis. 100:1030.

Yamakawa, Y. 1989. Virus reinfection of virus-free Cabernet sauvignon and Cabernet franc vines. J. Jpn. Soc. Hortic. Sci. 58:297-302.

Zhang, Y.-P., Uyemoto, J. K., Golino, D. A., and Rowhani, A. 1998. Nucleotide sequence and RT-PCR detection of a virus associated with grapevine rupestris stem-pitting disease. Phytopathology 88:1231-1237. 